\title{
Harga Diri ditinjau dari Kualitas Relasi Ayah pada Mahasiswa-mahasiswi yang Tinggal di Asrama Universitas Prima Indonesia Medan
}

\author{
Debby Mellita, Sri Hartini, Yulinda Septiani Manurung \\ Fakultas Psikologi Universitas Prima Indonesia \\ email: debbymelita10@gmail.com
}

\begin{abstract}
Abstrak
Beberapa penelitian sebelumnya telah membuktikan harga diri memiliki peranan penting untuk mencapai kebahagiaan, kesejahteraan subjektif, serta mempengaruhi kepercayaan diri individu. Proses pembentukan harga diri diasumsikan memiliki kaitanyang erat dengan pengalaman yang diperoleh dari pengasuhan keluarga, salah satunya yaitu kualitas relasi ayah.Penelitian ini bertujuan untuk mengetahui hubungan antara kualitas relasi ayah dengan harga diri.. Subjek penelitian dalam penelitian ini adalah mahasiswa/i yang tinggal di asrama Universitas Prima Indonesia sebanyak 139 orang yang dipilih dengan metode purposive sampling. Data diperoleh dari skala untuk mengukur kualitas relasi ayah dan harga diri. Perhitungan dilakukan dengan melalui uji prasyarat analisis (uji asumsi) yang terdiri dari uji normalitas dan uji linearitas hubungan. Analisis data yang digunakan adalah menggunakan korelasi Product Moment melalui bantuan SPSS 21 for Windows. Hasil analisis data menunjukan koefisien korelasi sebesar 0,647 dengan $p$ sebesar 0,000 ( $p<$ $0,05)$. Ini menunjukkan ada hubungan positif antara kualitas relasi ayah dengan harga diri. Hasil penelitian ini menunjukkan bahwa sumbangan yang diberikan variabel kualitas relasi ayah terhadap harga diri adalah sebesar 41,9 persen. Dari hasil penelitian ini menunjukan bahwa hipotesis dapat diterima bahwa ada hubungan positif antara kualitas relasi ayah dengan harga diri.
\end{abstract}

Kata Kunci: Harga Diri, Kualitas Relasi Ayah, Korelasi

\section{Correlation Between Father-child Relationship and Self-Esteem in University Students who living in a Universitas Prima Indonesia Dormitory}

\begin{abstract}
Previous studies have shown that self-esteem is an important predictor of happiness, subjective well being, and confidence. The development of self-esteem is strongly influenced by parental behavior and attitude like father-child relationship. This study aims to determine the relationship between father-child relationship with self-esteem.. The research subjects were 139 students who live in University of Prima Indonesia Medan Dorms selected by purposive sampling. Data were obtained from a scale to measure father-child relationship and self-esteem. The calculation was performed by means of testing requirements analysis (assumption) that consists of a test for normality and linearity test for relationships. The Analysis of the data was performed by Product Moment Correlation with SPSS 21 for Windows. The results of data analysis showed that the coefficient was 0.647 and $p 0.000(p<0.05)$. It showed that there is a positive correlation between father-child relationship and self-esteem These results indicate that the contribution given to self-esteem by father-child relationship variable was 41.9 percent. From the results, this study showed that the hypothesis is accepted that there is a positive relationship between father-child relationship with self-esteem.
\end{abstract}

Keywords: Father-child Relationship, Self-esteem, Correlation 


\section{Pendahuluan}

Sejak manusia lahir, proses interaksi sudah mulai dilakukan walaupun hanya terbatas pada hubungan antara seorang bayi dan ibunya. Interaksi tersebut akan terus meluas dan mengembangkanself(diri)yang sudah ada sejak manusia lahir. Self pada awalnya merupakan gambaran yang samarsamar berkembang hingga sampai kepada suatu perasaan identitas diri yang jelas dan tepat. Mecca, dkk., (1989) mendefinisikan self sebagai keseluruhan yang kompleks dan merupakan sebuah sistem yang bersifat dinamis. Artinya, self adalah sebuah konsep yang terus berubah dan berkembang dengan cara yang berbeda-beda sehingga menjadi ciri unik setiap individu. Proses pembentukan self sangat erat kaitannya dengan pengalaman yang diperoleh individu sebagai hasil dari interaksi. Perasaan akan diri sudah mulai ada ketika anak-anak sudah menjalin interaksi, dan kesadaran akan diri pun semakin kuat seiring bertambahnya usia. Kesadaran tersebut ditandai dengan adanya self-talk yang semakin jelas dalam pikiran. Self-talk merupakan dialog internal yang terjadi dalam diri. Percakapan tersebut merupakan tindakan yang dilakukan untuk menginterpretasi atau memaknai peristiwa yang terjadi dan percakapan tersebut akan mempengaruhi suasana perasaan dan tingkah laku individu (Mead, 1934).

Keluarga merupakan kelompok sosial pertama dalam kehidupan manusia. Pemahaman mengenai diri juga mulai berkembang dari lingkungan keluarga. Seorang anak mulai mengenali siapa dan seperti apakah dirinya melalui atribut yang diberikan orang tuanya. Satiadarma (2001) menjelaskan bahwa persepsi orangtua mempengaruhi sikap orang tua terhadap anak-anak mereka, dan anakanak cenderung mengembangkan penilaian terhadap diri berdasarkan label serta atribut yang diberikan orang tua kepada dirinya. Adakalanya label dan atribut tersebut bersifat positif sifatnya sehingga anak-anak tersebut menyandang hal-hal positif yang lambat laun berkembang secara positif dalam diri mereka, namun adakalanya label dan atribut tersebut bersifat negatif sehingga hal-hal negatif itu pun secara bertahap akan mengembangkan sifat-sifat negatif. Hal tersebut dikarenakan anak cenderung meyakini anggapan orang di sekitarnya terhadap dirinya. Apabila anak mengembangkan keyakinan negatif terhadap dirinya akan cenderung terhambat, hal tersebut disebabkan karena perasaan atau keyakinan bahwa dirinya tidak mampu memenuhi ekspetasi, tidak disayang, maupun perasaan bahwa dirinya tidak berguna. Keyakinan yang negatif juga merupakan salah satu penyebab individu mengalami kecemasan dan depresi, sertakecenderunganindividuuntukmelakukan hal-hal menyimpang seperti terlibat dalam pergaulan tidak sehat, penyalahgunaan narkotika, atau bahkan bunuh diri.

Penilaian positif ataupun negatif terhadap diri sebagai objek dikenal dengan istilah harga diri. Harga diri didefinisikan oleh Santrock (2007) sebagai suatu dimensi penilaian secara global mengenai diri. Harga diri merupakan dasar dari berbagai aspek kesehatan mental dan merupakan kunci kebahagiaan. Harga diri yang positif membantu individu untuk mampu mengatasi permasalahan serta memiliki penyesuaian diri yang baik. Tafarodi dan Swann (dalam Matsumoto, 2001) menjelaskan bahwa harga diri merupakan variabel yang multidimensi, dimana harga diri tidak hanya sekedar perasaan positif atau negatif. Namun meliputi persepsi suka atau tidak suka terhadap diri yang menghasilkan perasaan acceptableunacceptable, serta persepsi kemampuan yang dimiliki sehingga menghasilkan perasaan strong-weak. Perasaan tersebut didapatkan dari penilaian secara keseluruhan terhadap dirinya yang diuraikan ke dalam dua dimensi, yaitu: (1) Self-competence, merupakan penilaian secara keseluruhan pengalaman atau prestasi yang pernah dicapai yang akan membuat kesimpulan mengenai dirinya sebagai individu yang kuat atau lemah. Biasanya individu menilai dirinya secara positif ketika individu merasa dirinya berkompeten.(2) Self-liking, yaitu mengenai sejauh mana individu tersebut menerima dirinya dan merasa dirinya bernilai. Self-liking merupakan bentuk penerimaan diri. Dengan 
kata lain, individu tidak mempermasalahkan kekurangan pada dirinya, berarti individu tersebut telah merasa nyaman dan memiliki penilaian positif terhadap dirinya.

Pembentukan harga diri dipengaruhi oleh berbagai faktor. Keluarga sebagai lingkungan pertama pembentukan harga diri, diyakini memberi pengaruh yang besar. Baik ibu maupun ayah memegang peran yang sangat penting dalam perkembangan anak, tetapi dikarenakan masih banyak yang beranggapan bahwa ayah hanya sebagai tulang punggung keluarga sehingga pengasuhan hanya dilakukan oleh ibu, kenyataannya perkembangan anak juga membutuhkan kehadiran seorang ayah.

Pada awalnya penelitian mengenai pengasuhan hanya terfokus pada ibu, seperti kelekatan dengan orang tua oleh Bowlby, dan penelitian mengenai pola asuh oleh Baumrid hanya menekankan pada pengasuhan yang diberikan oleh ibu (Dagun, 2002), Namun belakangan ini, penelitian terhadap dampak pengasuhan dan kehadiran seorang ayah terhadap perkembangan anak mulai mendapatkan perhatian khusus. Penelitian terhadap berbagai sisi peran ayah seperti keterlibatan ayah dalam pengasuhan, dukungan sosial dari ayah, serta kualitas relasi ayah memberikan dampak terhadap perkembangan kesehatan mental anak, terutama dalam hal pembentukan harga diri. Salah satunya penelitian yang dilakukan oleh Widiastuti dan Widjaja (2004) ditemukan adanya hubungan positif antara kualitas relasi ayah dengan harga diri remaja. Artinya, semakin tinggi kualitas hubungan dengan ayah akan membentuk harga diri yang tinggi pada anak dibandingkan dengan anak yang memiliki kualitas relasi ayah yang rendah.

Kualitas relasi ayah didefinisikan oleh Ellison dan Hummer (2010) sebagai seberapa baik hubungan yang terjalin antara ayah dan anak. Sebuah relasi memiliki kualitas yang tinggi apabila adanya kedekatan, kepercayaan, pengertian serta afektif yang positif dalam hubungan. Begitu juga dengan Wilcox dan Kline (2013) turut mendefinisikan kualitas relasi adalah seberapa erat kedekatan yang dirasakan oleh anak terhadap ayahnya.
Tinggi rendahnya kualitas relasi dengan ayah dipengaruhi oleh kepuasan terhadap keseluruhan waktu dan aktivitas yang dilakukan bersama ayah.

Lamb (2010) mengemukakan tiga dimensi dari kualitas relasi dengan ayah yaitu: Interaction, merupakan interaksi antara ayah dan anak, atau jumlah waktu yang dihabiskan oleh orang tua untuk melakukan aktivitas dengan anak, responsiveness, yaitu daya tanggap ayah terhadap permintaan atau kebutuhan anaknya, beberapa bentuk tanggapan sepertiberbicara dengananak, atau turut membantu anak, serta emotional quality, merupakan bentuk afektif, meliputi emosi negatif atau emosi positif dalam hubungan dengan ayahnya. Apabila secara keseluruhan anak merasa puas terhadap ayahnya maka akan memiliki perasaan yang positif terhadap hubungannya dengan ayah.Kindlon (2006) menyatakan bahwa dalam kualitas hubungan yang dibina ayah dengan anaknya sangat penting untuk kesehatan mental anaknya. Baik pada putra maupun putri, mereka yang memiliki kualitas hubungan yang baik dengan ayahnya akan memiliki harga diri yang lebih tinggi.

Maka berdasarkan uraian diatas, maka peneliti tertarikmelakukan penelitian untuk menguji hubungan antara kualitas relasi ayah dengan harga diri, Adapun bunyi hipotesa yang diajukan dalam penelitian ini yaitu sebagai berikut: ada hubungan positif antara kualitas relasi ayah dengan harga diri, dimana semakin tinggi kualitas relasi ayah, maka harga diri subjek akan tinggi, sebaliknya jika semakin rendah kualitas relasi ayah maka harga diri subjek cenderung rendah.

\section{Metode \\ Subjek}

Subjek pada penelitian ini adalah mahasiswa yang tinggal di asrama Universitas Prima Indonesia yang berjumlah 226 orang. Jumlah sampel pada penelitian ini diambil menggunakan ketentuan yang diungkap oleh Isaac Michael (dalam Sugiyono, 2011) dengan perhitungan jumlah sampel minimal sebanyak 139 orang untuk taraf kesalahan 5\%. Teknik pengambilan sampel yang digunakan dalam 
penelitian ini adalah purposive sampling. Sugiyono(2011)menjelaskanbahwa purposive sampling adalah pengambilan sampel dengan pertimbangan tertentu, purposive sampling merupakan teknik pengambilan sampel yang dilakukan apabila sampel yang diteliti harus memiliki kriteria tertentu. Adapun kriteria subjek dalam penelitian ini adalah mahasiswa dan mahasiswi yang tinggal di asrama berusia 20 hingga 24 tahun dan memiliki ingatan mengenai hubungan dengan ayah.

Pengukuran

Metode pengumpulan data yang digunakan dalam penelitian ini dengan menggunakan metode pembagian skala untuk mengukur harga diri dan kualitas relasi ayah. Jenis skala yang digunakan adalah skala Likert. Dengan skala Likert, maka variabel yang akan diukur dijabarkan menjadi indikator variabel. Indikator atau komponen-komponen tersebut dijadikan titik tolak untuk menyusun aitem-aitem instrument yang berupa pernyataan (Sugiyono, 2011). Skala yang digunakan dalam penelitian ini menggunakan empat alternatif jawaban yaitu SS (sangat setuju), S (setuju), TS (tidak setuju), dan STS (sangat tidak setuju), yang mana pernyataan favourable maka mengandung nilai-nilai yang positif, SS (sangat setuju) diberikan bobot 4 (empat), S (setuju) dengan bobot 3 (tiga), TS (tidak setuju) dengan bobot 2 (dua), dan STS (sangat tidak setuju) dengan bobot 1 (satu). Sistem penilaian sebaliknya, jika pernyataan unfavourable yaitu SS (sangat setuju) diberikan bobot 1 (satu), $S$ (setuju) dengan bobot 2 (dua), TS (tidak setuju) dengan bobot 3 (tiga), dan STS (sangat tidak setuju) dengan bobot 4 (empat). Skala yang digunakan dalam penelitian ini terdiri atas dua skala yaitu skala harga diri dan skala kualitas relasi ayah.

Skala harga diri .Skala ini terdiri dari 21 butir pernyataan, disusun berdasarkan dimensi harga diri yang dikemukakan oleh Tafarodi dan Swann (dalam Matsumoto, 2001), yaitu dimensi self competence sebagai penilaian secara keseluruhan pengalaman atau prestasi yang pernah dicapai, serta dimensi self-liking, yaitu mengenai sejauh mana individu tersebut menerima dirinya dan merasa dirinya bernilai. Skala Kualitas
Relasi Ayah. Skala ini diungkap dengan menggunakan skala yang terdiri dari 51 butir pernyataan, disusun berdasarkan dimensi kualitas relasi ayah yang dikemukakan oleh Lamb (2010), yaitu dimensi interaction yang meliputi jumlah waktu yang dihabiskan oleh ayah untuk melakukan aktivitas dengan anak, dan dimensi responsiveness atau daya tanggap ayah terhadap permintaan dan kebutuhan anaknya, serta dimensi emotional quality atau sikap yang meliputi emosi negatif atau emosi positif dalam hubungan dengan ayahnya.

Validitas dan reliabilitas memegang peranan yang sangat penting dalam penelitian. Sebelum alat ukur tersebut dipakai, lebih dahulu harus diukur tingkat validitas setiap butir dan reliabilitas alat ukur. Substansi yang terpenting dalam validasi skala psikologi adalah membuktikan bahwa struktur seluruh aspek keperilakuan, indikator keperilakuan dan aitem-aitemnya memang membentuk suatu konstruk yang akurat bagi atribut yang diukur (Azwar, 2012). Dengan adanya validitas dan reliabilitas yang tinggi akan memberikan informasi yang baik mengenai keadaan subjek yang diteliti.

\section{Uji Validitas}

Menurut Arikunto (2006), validitas adalah suatu ukuran yang menunjukkan tingkat kevalidan atau kesahihan suatu instrumen. Suatu instrumen yang valid dan sahih mempunyai validitas yang tinggi, sebaliknya instrumen yang kurang valid dan sahih mempunyai validitas yang rendah. Jenis validitas yang digunakan dalam penelitian ini adalah validitas isi.

Validitas isi merupakan validitas yang diestimasi lewat pengujian terhadap isi tes dengan analisis rasional atau lewat professional judgement. Validitas isi menunjuk kepada sejauh mana isi sebuah tes/skala/instrumen dapat mengukur apa yang seharusnya diukur. Validitas isi pada alat ukur berupa skala tercapai apabila butirbutir pernyataan skala mengukur aspek yang relevan. Pemilihan butir-butir pernyataan dilakukan terlebih dahulu dengan melakukan pengujian terhadap kualitas pernyataan.

Menurut Azwar (2009), validitas isi 
terbagi menjadi dua tipe, yaitu: (1) Validitas muka,merupakan tipe validitas yang paling rendah signifikansinya karena hanya didasarkan pada penilaian terhadap format penampilan (appearance) tes. Apabila penampilan tes telah meyakinkan dan memberikan kesan mampu mengungkap atribut yang hendak diukur, maka dapat dikatakan bahwa validitas muka telah terpenuhi. Namun demikian validitas muka tetap penting artinya guna membangun kredibilitas tes dan selanjutnya meningkatkan motivasi individu untuk menjawabtes, terutama pada tes yang dimaksudkan untuk mengukur performansi maksimal. Tanpa adanya validitas muka, tes tidak akan memperoleh apresiasi yang layak dari responden dan akibatnya lebih lanjut adalah berkurangnya kesungguhan responden dalam mengisi tes. (2) Validitas logic, disebut juga validitas sampling. Validitas tipe ini menunjuk pada sejauh mana isi tes merupakan wakil dari ciriciri atribut yang hendak diukur sebagaimana telah ditetapkan dalam kawasan ukurnya. Azwar (2012) menyatakan bahwa dalam seleksi aitem skala psikologi yang mengukur atribut afektif, parameter yang paling penting adalah daya beda atau daya diskriminasi aitem. Daya diskriminasi aitem adalah sejauh mana aitem mampu membedakan antara individu atau kelompok individu yang memiliki dan yang tidak memiliki atribut yang diukur. Parameter daya beda aitem yang berupa koefisien korelasi aitem-total memperlihatkan kesesuaian fungsi aitem dengan fungsi skala dalam mengungkap perbedaan individual. Dengan demikian, guna mengoptimalkan fungsi skala, maka sangat logis apabila pemilihan aitem-aitem didasarkan pada besarnya koefisien korelasi.

Besarnya koefisien validitas bergerak dari 0 sampai dengan 1,00. Daya diskriminasi aitem yang baik adalah mempunyai koefisien validitas yang mendekati angka 1,00. Azwar (2010) menyatakan bahwa koefisien validitas aitem minimal mencapai 0,30 . Teknik yang digunakan untuk menguji daya diskriminasi aitem adalah dengan menggunakan metode korelasi Pearson atau metode Corrected Item-Total Correlation dengan bantuan SPSS

\section{1 for windows.}

Uji Reliabilitas

Reliabilitas adalah taraf keterpercayaan atau taraf konsistensi hasil ukur (Azwar, 2012). Besarnya koefisien reliabilitas banyak dipengaruhi antara lain oleh heterogenitas skor yang ada dalam kelompok tersebut. Pada umumnya, reliabilitas telah dianggap memuaskan bila besar koefisiennya mencapai $r_{x x^{\prime}}=0,900$. Koefisien reliabilitas mencerminkan hubungan skor skala yang diperoleh $(\mathrm{X})$ dengan skor yang sesungguhnya (skor-murni) yang tidak dapat diketahui $(\mathrm{T})$ maka dengan koefisien reliabilitas 0,900 berarti perbedaan yang tampak pada skor skala tersebut mencerminkan $90 \%$ dari variasi yang terjadi pada skor murni kelompok subjek yang bersangkutan. Dengan kata lain dapat dikatakan bahwa $10 \%$ dari perbedaan skor yang tampak adalah akibat variasi eror atau kesalahan pengukuran tersebut.

Estimasi terhadap tingginya reliabilitas alat ukur digunakan dalam penelitian ini melalui metode pendekatan konsistensi antara aitem atau antar bagian dalam tes itu sendiri. Pendekatan ini dilakukan dengan menggunakan satu bentuk tes yang dikenakan hanya sekali saja pada sekelompok subjek. Teknik yang digunakan untuk menguji reliabilitas alat ukur peneliti adalah dengan teknik SPSS menggunakan metode Alpha Cronbach.

\section{Analisis Data}

Teknik analisis yang digunakan untuk menganalisis data hasil penelitian ini adalah teknik korelasi Product Moment dari Pearson dengan menggunakan program SPSS 21 for windows. Sebelum data-data yang terkumpul dianalisa, terlebih dahulu dilakukan uji asumsi yang meliputi:, Uji Normalitas, yaitu digunakan untuk mengetahui apakah data terdistribusi dengan normal atau tidak. Korelasi Product Moment mensyaratkan bahwa data harus terdistribusi dengan normal, dan dalam hal ini digunakan Kolmogorov Smirnov Z. Adapun kriteria yang digunakan adalah apabila $p>0,05$ maka data berdistribusi normal dan sebaliknya jika $p<0,05$ maka tidak berdistribusi normal (Priyatno, 2011).Uji Linearitas, bertujuan untuk mengetahui apakah dua variabel yang akan 
dikenai prosedur analisis statistik korelasional menunjukkan hubungan yang linier atau tidak. Jika $p<0,05$ maka hubungan antara kedua variabel yaitu kualitas relasi ayah dan harga diri dikatakan linier, sebaliknya jika $p>0,05$ maka hubungan kedua variabel dikatakan tidak linier (Priyatno, 2011).

Hasil

Skor Variabel Harga Diri

Skala harga diri terdiri dari 21 aitem dengan skor aitemnya yang bergerak dari empat pilihan jawaban dengan skor satu sampai empat. Rentang maksimum dan minimumnya adalah $21 \times 1$ sampai $21 \times 4$, yaitu 21 sampai 84 dengan mean hipotetiknya $(21+84): 2=52,5$. Standard deviasi hipotetik dalam penelitian ini adalah (84-21) : $6=10,5$. Dari skala harga diri yang diisi subjek, maka diperoleh mean empirik sebesar 64,34 dengan standard deviasi 9,760.

\section{Tabel 1. Perbandingan Data Empirik dan Hipotetik Harga Diri}

\begin{tabular}{|c|c|c|c|c|c|c|c|c|}
\hline \multirow{2}{*}{ Variabel } & \multicolumn{3}{|c|}{ Empirik } & \multirow{2}{*}{ SD } & \multicolumn{3}{|c|}{ Hipotetik } & \multirow[t]{2}{*}{ SD } \\
\hline & Min & Max & Mean & & Min & Max & Mean & \\
\hline Harga Diri & 46 & 84 & 64,42 & 9,586 & 21 & 84 & 52,5 & 10,5 \\
\hline
\end{tabular}

Apabila mean empirik >mean hipotetik maka hasil penelitian yang diperoleh akan dinyatakan tinggi dan sebaliknya jika mean empirik <mean hipotetik maka hasil penelitian akan dinyatakan rendah.

Hasil analisis untuk skala harga diri diperoleh mean empirik $>$ mean hipotetik yaitu 64,42 > 52,5 maka dapat disimpulkan bahwa harga diri pada subjek penelitian lebih tinggi daripada populasi pada umumnya. Skor Variabel Kualitas Relasi Ayah
Skala kualitas relasi ayah terdiri dari 51 aitem dengan skor aitem yang bergerak dari empat pilihan jawaban dengan skor satu sampai empat. Rentang maksimum dan minimumnya adalah $51 \times 1$ sampai $51 \times 4$, yaitu 51 sampai 204 dengan mean hipotetiknya $(51+204): 2=127,5$. Standar deviasi hipotetik dalam penelitian ini adalah (204-51) : $6=$ 25,5. Dari skala kualitas relasi ayah yang diisi subjek, maka diperoleh mean empirik sebesar 157,45 dengan standar deviasi 23,204.

Tabel 2. Perbandingan Data Empirik dan Hipotetik Kualitas Relasi Ayah

\begin{tabular}{|c|c|c|c|c|c|c|c|c|}
\hline \multirow{2}{*}{ Variabel } & \multicolumn{3}{|c|}{ Empirik } & \multirow[b]{2}{*}{ SD } & \multicolumn{3}{|c|}{ Hipotetik } & \multirow{2}{*}{ SD } \\
\hline & Min & Max & Mean & & Min & Max & Mean & \\
\hline Kualitas & ?0 & 201 & 157,4 & 23,18 & 51 & 001 & ז7 & 255 \\
\hline Relasi Ayah & Y. & 201 & 6 & 9 & 31 & $\angle 04$ & $1 \angle T, 0$ & $2 J, J$ \\
\hline
\end{tabular}

Apabila mean empirik >mean hipotetik maka hasil penelitian yang diperoleh akan dinyatakan tinggi dan sebaliknya jika mean empirik <mean hipotetik maka hasil penelitian akan dinyatakan rendah.

Hasil analisis untuk skala Kualitas Relasi Ayah diperoleh mean empirik >mean hipotetik yaitu 157,46 > 127,5 maka dapat disimpulkan bahwa kualitas relasi ayah pada subjek penelitian lebih tinggi daripada populasi pada umumnya.

Hasil Uji Asumsi

Uji asumsi yang digunakan dalam penelitian ini adalah uji normalitas dan uji linearitas.Ujinormalitassebaranmenggunakan uji Kolmogorov Smirnov Test (K-SZ). Data dikatakan berdistribusi normal jika $p>0.05$ (Priyatno, 2010). Uji normalitas pada variabel kualitas relasi ayah diperoleh koefisien KS-Z $=1,006$ dengan Sig sebesar 0,263 untuk uji 2 
(dua) arah/Sig. 2 tailed, sedangkan penelitian ini menggunakan hipotesa satu arah, sehingga yang dipakai adalah uji 1 (satu) arah/Sig. 1-tailed sebesar 0,131 ( $p>0.05)$, yang berarti bahwa data pada variabel kualitas relasi ayah memiliki sebaran atau berdistribusi normal. Uji normalitas yang dilakukan terhadap variabel harga diri diperoleh koefisien $\mathrm{KS}-\mathrm{Z}=1,071$ dengan Sig sebesar 0,202 untuk uji 2 (dua) arah/Sig. 2-tailed dan untuk uji 1 (satu) arah/ Sig. 1-tailed sebesar 0,101 ( $p>0.05$ ), yang berarti bahwa data pada variabel harga diri memiliki sebaran atau berdistribusi normal.

\section{Tabel 3.Hasil Uji Normalitas}

\begin{tabular}{cccccc}
\hline Variabel & SD & KS-Z & Sig. & P & Keterangan \\
\hline Kualitas & 23,189 & 1,006 & 0,131 & $\mathrm{p}>0.05$ & Sebaran normal \\
Relasi Ayah & 2,586 & 1,071 & 0,101 & $\mathrm{p}>0.05$ & Sebaran normal \\
Harga diri & 9,586 \\
\hline
\end{tabular}

Uji linearitas digunakan untuk mengetahui apakah distribusi data penelitian yaitu variabel kualitas relasi ayah dan harga diri memiliki hubungan linear Uji F (Anova). Variabel harga diri dan kualitas relasi ayah dikatakan memiliki hubungan linear jika $p<0.05$. Variabel kualitas relasi ayah dan harga diri dalam penelitian ini mempunyai hubungan linear. Hal ini terlihat dari nilai sig. yang diperoleh yaitu 0.000 maka $\mathrm{p}<0.05$, dapat disimpulkan bahwa kedua variabel memiliki hubungan linear dan telah memenuhi syarat untuk dilakukan analisa korelasi Product Moment.

Setelah uji asumsi diterima, selanjutnya dilakukan uji hipotesis. Hipotesis dalam penelitian ini adalah terdapat hubungan positif antara kualitas relasi ayah dengan harga diri. Berdasarkan tujuan penelitian maka dilakukan uji Pearson Correlation. Berdasarkan hasil analisis korelasi antara kualitas relasi ayah dengan harga diri diperoleh koefisien korelasi product moment sebesar $r=0,647$ dengan sig sebesar $0.000(p<0.05)$. Hal ini menunjukkan bahwa adanya korelasi positif antara kualitas relasi ayah dengan harga diri. Adapun kuatnya hubungan antara kualitas relasi ayah dengan harga diri tergolong kategori sedang.

Dari hasil perhitungan tersebut, maka hipotesis yang diajukan dalam penelitian ini menunjukkan ada hubungan positif antara kualitas relasi ayah dengan harga diri dapat diterima. Dengan demikian, dapat disimpulkan bahwa semakin tinggi kualitas relasi ayah maka semakin tinggi harga diri pada seorang remaja, dan sebaliknya semakin rendah kualitas relasi ayah maka semakin rendah pula harga diri individu.

\section{Pembahasan}

Hasil penelitian pada 139 mahasiswa yang tinggal di asrama Universitas Prima Indonesia Medan sebagai subjek penelitian, diperoleh hasil bahwa ada hubungan positif antara kualitas relasi ayah dengan harga diri, dengan koefisien korelasi Product Moment sebesar $r=0,647$ dan nilai $p=0.000$, artinya adanya hubungan yang kuat dan berbanding lurus antara kualitas relasi ayah dengan harga diri, dimana semakin tinggi/baik kualitas relasi ayah maka semakin tinggi pula harga diri seorang anak, dan sebaliknya apabila semakin rendah kualitas relasi ayah maka harga diri pada anak cenderung rendah.

Hasil penelitian diatas, sejalan dengan pendapat Taitt (2006) yang menyatakan bahwa seorang ayah memainkan peran utama dalam membangun harga diri baik putra maupun putrinya. Perlindungan dan pujian yang diberikan oleh ayah kepada putrinya, akan membantu putrinya memahami bahwa dirinya berharga dan layak mendapatkan yang terbaik. Sementara ayah merupakan seorang model maskulinitas bagi putranya, ayah merupakan figur yang dibutuhkan anak laki-laki uwntuk melakukan identifikasi, pengakuan yang diberikan ayah atas pencapaian putranya akan memberikan kepuasan baginya. Pernyataan tersebut juga sepadan dengan Kindlon (2006) yang menyatakan bahwa dalam kualitas hubungan 
yang dibina ayah dengan anaknya sangat penting untuk kesehatan mental anaknya. Baik pada putra maupun putri, mereka yang memiliki kualitas hubungan yang baik dengan ayahnya akan memiliki harga diri yang lebih tinggi. Selanjutnya, hasil penelitian ini sesuai dengan penelitian yang dilakukan oleh Zia, dkk., (2015), kepada 321 remaja yang berusia 13 hingga 21 tahun yang menunjukkan adanya hubungan yang signifikan dan positif antara kualitas relasi ayah dengan harga diri, dengan korelasi yaitu $(r=0,763, p<0,05)$.

Pada penelitian ini diperoleh koefisien determinasi $R$ Square $\left(R^{2} R^{2}\right)$ sebesar 0,419 . Berdasarkan hasil tersebut, dapat disimpulkan bahwa sebanyak 41,9 persen sumbangan yang diberikan oleh variabel kualitas relasi ayah terhadap harga diri pada mahasiswa yang tinggal di asrama Universitas Prima Indonesia, selebihnya 58,1 persen dipengaruhi oleh faktor lain yang tidak diteliti dalam penelitian ini, seperti dukungan sosial yang diterima, penggunaan sosial media yang intens, serta tipe kepribadian Big Five.

Berdasarkan hasil wawancara pada kelompok partisipan kualitas relasi ayah yang rendah, hubungan antara subjek dengan ayahnya terasa kurang akrab disebabkan padatnya jadwal pekerjaan ayah mereka sehingga jarang mendapatkan kesempatan dan perhatian dari ayah. Beberapa partisipan menggambarkan sosok ayah sebagai orang yang tidak peduli dengan aktivitas mereka dan sulit mengekspresikan kasih sayang. Beberapa partisipan juga merasa kaku saat mengobrol dengan ayah karena tidak terbiasa. Tingkat harga diri pada kelompok partisipan ini juga tergolong kategori menegah kebawah, beberapa partisipan merasa tidak nyaman dengan kelemahan pada diri, beberapa partisipan juga mengakui sering merasa minder dan ragu dengan kemampuan mereka.

Berdasarkan hasil wawancara pada kelompok partisipan yang memiliki kualitas relasi ayah yang tinggi, rata-rata telah menjalin kedekatan dengan ayah sejak kecil. Beberapa partisipan menceritakan bahwa nasihat dan masukan dari ayah sangat membantu mereka mengatasi masalah. Dukungan dan apresiasi yang diberikan ayah menambah kepercayaan diri mereka, pada kelompok partisipan ini juga tergolong kategori harga diri yang tinggi, mereka merasa puas dan bangga dengan pencapaian mereka, partisipan juga mengakui bahwa dirinya aktif untuk terus mengasah potensi dalam diri.

Kualitas relasi antara anak dengan ayah yang baik terbentuk dari adanya interaksi positif. Aktivitas yang dilakukan bersama ayah cenderung lebih menantang, kompetitif yang melibatkan aktivitas motorik maupun kognitif, secara tidak langsung dapat mengasah self-competence, serta penerimaan pengakuan dan pujian dari ayah yang membuat anak merasa dirinya bernilai. seseorang yang menjalin hubungan baik atau memiliki kedekatan dengan ayahnya, menerima kasih sayang, kepercayaan, serta mendapatkan pengakuan dan dukungan dari ayahnya sejak kecil akan membangun harga diri yang baik, yang menjadikan seseorang mampu menghargai diri, atau memiliki self-liking dalam arti menerima kelebihan maupun kekurangan dalam dirinya, serta memiliki self-competence yaitu mengenal batas kemampuan mereka dan kemauan mengembangkan potensi dengan baik. Sebaliknya, kualitas relasi ayah yang buruk seperti kegagalan menjalin komunikasi yang baik, kurangnya interaksi positif dengan ayah menyebabkan hubungan dengan ayah terasa kaku, kurangnya perhatian dan dukungan dari ayah akan membentuk keyakinan bahwa dirinya kurang bernilai menyebabkan harga diri yang rendah.

\section{Kesimpulan}

Berdasarkan hasil-hasil yang telah diperoleh dalam penelitian ini, maka dapat disimpulkan adanya hubungan positif antara kualitas relasi ayah dengan harga diri, artinya subjek yang memiliki kualitas relasi dengan ayah yang tinggi, cenderung memiliki harga diri yang tinggi. Sebaliknya semakin rendah kualitas relasi ayah yang dimiliki subjek, maka semakin rendah pula tingkat harga diri.Mean dari harga diri pada subjek penelitian mahasiswa yang tinggal di asrama Universitas Prima Indonesia Medan 
secara keseluruhan menunjukkan bahwa subjek penelitian menunjukkan kategori tinggi.Hasil penelitian ini menunjukkan bahwa sumbangan yang diberikan variabel kualitas relasi ayah terhadap variabel harga diri adalah sebesar 41,9 persen, selebihnya 58,1 persen dipengaruhi oleh faktor lain yang tidak diteliti dalam penelitian ini

\section{Daftar Pustaka}

Arikunto, S. (2014). Prosedur Penelitian Suatu Pendekatan Praktik. Jakarta: Rineka Cipta.

Azwar, S. (2009). Metode Penelitian edisi 1. Yogyakarta: Pustaka Belajar.

Azwar, S. (2012). Penyusunan Skala Psikologi edisi 2. Yogyakarta: Pustaka Belajar.

Dagun, S. M. (2002). Psikologi Keluarga. Jakarta: Rineka Cipta.

Ellison, C. G \& Hummer, R. A. (2010). Religion Families and Health. New Jersey: Rutgers University Press.

Kindlon, D. (2006). Alpha Girls:Understanding the New American Girl and How She Is Changing The World. New York: Rodale.

Lamb, M. E. (2010). The Role Of Father in Child Development: fifth edition. Canada: John Wiley \& Sons, Inc.

Matsumoto, D. (2001). The Handbook of Culture and Psychology. New York: Oxford University Press.

Mead, G. H (1934). Mind, Self and Society: The definitive Edition. Chigago: The University of Chigago Press

Mecca, A. M., Smelser N. J., \& Vasconcellos. J. (1989). Social Importance of Self Esteem. California: University of California Press.

Priyatno, D. (2011). Buku Saku Analisis Statistik Data SPSS. Yogyakarta: Penerbit Mediakom.

Santrock, J. W. (2007). Remaja, Edisi kesebelas. Jakarta: Penerbit Erlangga.

Satiadarma, M. P. (2001). Persepsi Orang Tua Membentuk Perilaku Anak. Jakarta: Penerbit Yayasan Pustaka Obor Indonesia.
Sugiyono. (2011). Metode Penelitian Administrasi: Dilengkapidengan Metode $R \& D$. Bandung: Penerbit Alfabeta.

Taitt, L. (2006). Father Me. United States of America: Xulon Press.

Widiastuti, N. \& Widjaja, T. (2004). Hubungan Antara Kualitas Relasi Ayah dengan Harga Diri Remaja Putra. Jurnal Psikologi. Vol. 2. No. 1. Diakses dari: http://download.portalgaruda.org/article. php?article $=62931 \& \mathrm{val}=4564$

Wilcox, W. B \& Kline, K. K. (2013). Gender and Parenthood: Biological and Social Scientific Perspectives. New York: Columbia University Press.

Zia, A., Malik, A. A., \& Ali, S. M. (2015). Father and Daughter Relationship and It's Impact on Daughter's Self Esteem and Academic Achievement. Academic Journal of Interdisciplinary Studies. Vol. 4 No. 1 http://doi.org/10.5901/ mjss.2015.v4n1p311 